\title{
Cristianos nuevos de origen ibérico en el Reino de Nápoles en el siglo XVII
}

\author{
Pilar Huerga Criado * \\ Fundación Española de Historia Moderna
}

En el Reino de Nápoles, de donde fueron expulsados los judíos en 1541, se desarrolló una importante comunidad de cristianos nuevos que pervivió hasta mediados del siglo XVII. Entonces, cuando la comunidad se hallaba en vías de asimilación social, y por tanto de disolución, la Inquisición romana procedió contra muchos de sus miembros. Los procesos de fe desvelan la compleja composición de la comunidad, aglutinada en torno a dos grandes redes de parentesco: la de los Vaaz, de origen portugués, y la de los Vargas, originarios de la Corona de Aragón. Estas familias habían logrado posesiones feudales, títulos de nobleza y puestos preeminentes en la magistratura, atributos que los situaban entre los poderosos: pero la comunidad incluía también a familias e individuos más humildes. Sus contradicciones internas provocaron la ruptura de la solidaridad y esa falta de protección fue aprovechada por los inquisidores para juzgarlos e imponerles las penas reservadas para los herejes judaizantes.

Palabras Clave: comunidad marránica; judaizante; judeoconverso; Inquisición romana; proceso de fe.

New Christians of Iberian Descent in the Kingdom of Naples during the $17^{\text {th }}$ CenTURY.- In 1541, in the Kingdom of Naples, the Jews were expelled or converted to Christianity resulting in an important community of New Christians that flourished and remained until the mid- $17^{\text {th }}$. During a process of social assimilation and consequently dissolution, a significant number of the members of the community was subject to the Roman Inquisition. The faith trials reveal how complex the community composition was, linked mainly to two outstanding families: the Vaaz, of Portuguese origin, and the Vargas, natives of the Kingdom of Aragon. These families had acquired feudal properties, nobility titles and preeminent positions in magistracy, attributes which placed them among those who held effective power. But the community included more humble families and individuals as well. Internal conflicts led to a break in solidarity and inquisitors took advantage of lack of protection by judging and imposing severe sentences reserved for the Crypto-Jews.

Keywords: Marrano Community; Crypto-Jew; Converso; Roman Inquisition; Proceso de Fe.

\footnotetext{
*pilarhuerga@gmail.com
} 
Los cristianos nuevos -los portadores de esa identidad- entraron en la historia de los reinos ibéricos en los cien años largos transcurridos entre 1391 y 1496 . Irrumpieron de forma abrupta como consecuencia de las persecuciones y forzados bautismos de 1391, su número se incrementó notablemente a causa del decreto de expulsión de los judíos de los reinos de Castilla y Aragón en 1492, y cuatro años después, en 1496, los bautizados por la fuerza en Portugal se sumaron a los anteriores. Desde entonces, las comunidades de cristianos nuevos vivieron incrustadas en la sociedad de los reinos ibéricos, aunque, de forma paulatina durante largos períodos de tiempo, y aceleradamente en ciertas coyunturas, se fueron expandiendo por gran parte de Europa, siguiendo siempre el ritmo que marcaban las circunstancias históricas ${ }^{2}$. En el último tercio del siglo XVII, una nueva diáspora completó su desaparición de los reinos ibéricos, y con ella la de su identidad, porque finalmente se desdoblaron en judíos y cristianos. Por lo tanto, la historia de los cristianos nuevos no se inscribe exclusivamente en los reinos de la Península Ibérica. Ellos nutrieron las comunidades instaladas en Francia, en los estados italianos, en el norte de

${ }^{1}$ La terminología empleada -tanto por los contemporáneos como por los historiadorespara identificar a los descendientes de los judíos convertidos al cristianismo en los reinos ibéricos provoca una enorme confusión. El término cristianos nuevos, en su forma castellana o portuguesa, fue usado por los contemporáneos para distinguirlos colectivamente de los llamados cristianos viejos. Sin embargo, no fue de uso común fuera de los reinos ibéricos, donde dominaron denominaciones como «portugueses», «hombres de la nación», o «judíos», que no designaban con acierto a esa minoría. En Nápoles, aludiendo más a su origen que a su profesión religiosa, fueron habitualmente identificados como «ebrei». Los historiadores han divulgado otro término, el de «marranos» y su derivación «marránica» para la comunidad y la religiosidad. No resulta fácil elegir en cada momento el más atinado, ni es este el objeto de mi trabajo, pero conviene precisar que usaré la expresión «comunidad de cristianos nuevos», en lugar de la de «ebrei» utilizada en Nápoles, para referirme a la minoría en su conjunto, independientemente de la actitud religiosa individual, y daré el nombre de marranos, o comunidad marránica, a los que mantenían su fidelidad a la tradición mosaica. En ambos casos, serán términos usados con reservas.

${ }^{2}$ Un análisis de la producción y tendencias historiográficas acerca de los cristianos nuevos, en P. Huerga Criado, «El problema de la comunidad judeoconversa», en Historia de la Inquisición en España y América. III. Temas y problemas, J. Pérez VIllanueva Y B. EsCANDELl BonEt, dirs. (Madrid, 2000), 441-498. En la misma obra, destacan por sus aportaciones y planteamientos los capítulos de B. LÓPEZ BELINCHÓN, «Olivares contra los portugueses. Inquisición, conversos y guerra económica», en ibíd., 499-530; y M. SCHREIBER, «Cristianos nuevos de Madrid ante la Inquisición de Cuenca (1650-1670)», en ibíd., 531-556. 
Europa; es decir, que no sólo sobrevivieron como comunidad en los estados donde la presencia judía estaba prohibida, sino también en aquellos en los que los judíos fueron aceptados e incluso atraídos. Aunque muchos de ellos eligieron la reconversión y entraron en la judería, hubo quienes prefirieron mantenerse fuera de ella formando parte de esa comunidad informal, no reconocida oficialmente, que conservó una tradición propia cuyo origen estaba inextricablemente unido a los reinos ibéricos ${ }^{3}$.

Las comunidades de cristianos nuevos formaron una red que se superpuso al espacio europeo occidental, de modo que sus enclaves dispersos se hallaban conectados por múltiples relaciones. En dicha red -más o menos tupida según las zonas y los tiempos-, se incluyó la comunidad o comunidades de Nápoles, cuya génesis se retrasó hasta 1541, cuando se decretó la expulsión de los judíos del reino. La expulsión de 1492 había afectado a los judíos de Sicilia, pero no a los de Nápoles, que todavía no se hallaban bajo la soberanía de Fernando el Católico. Aún después de la conquista y durante casi cuarenta años más, continuaron viviendo en el reino. Es más, entre 1492 y 1541, la comunidad judía de Nápoles creció gracias a la incorporación de los expulsados de Sicilia, que fueron acogidos por Ferrante I en $1492^{4}$. Tras la conquista, la disparidad de situaciones entre los dominios de Sicilia y de Nápoles actuaría a favor de la emigración del primero al segundo, donde eran tolerados los judíos y donde no se había establecido la inquisición ${ }^{5}$. A partir de 1541, esa disparidad se redujo notablemente, no solo

${ }^{3}$ Identificó y caracterizó a esta comunidad I. S. RÉVAH, «Les marranes», RÉJ 118 (1959-60), 29-77. Por el abultado número de trabajos dedicados a estas comunidades, remito al repertorio bibliográfico de la obra de Federica Ruspio, que ha puesto de relieve la coexistencia de las comunidades de judíos y de cristianos nuevos: F. Ruspio, Nazione portoghese. Ebrei ponentini e nuovi cristiani a Venezia (Torino, 2009). Sobre la diáspora de los cristianos nuevos, estudiada en sus diferentes dimensiones, tienen gran interés las aportaciones recogidas en La Diaspora des Nouveaux-Chrétiens [= Arquivos do Centro Cultural Calouste Gulbenkian XLVIII (Lisboa-Paris, 2004)].

${ }^{4}$ Véase el ya clásico estudio de F. Ruiz Martín, «La expulsión de los judíos del Reino de Nápoles», Hispania IX (1949), 28-76 y 179-240.

${ }^{5}$ Calcula en cerca de 30.000 el número de judíos residentes en Sicilia en el momento de la expulsión V. Sciutti Russi, «Ebrei, Inquisizione, Parlamenti nella Sicilia del primo Cinquecento», en L'Inquisizione e gli ebrei in Italia, ed. M. LuzzATI (Roma-Bari, 1994), 161-178. Acerca de la acogida de los expulsados en Nápoles, R. BonfIL, «Italia: un triste epílogo de la expulsión de los judíos de España», en Judíos. Sefarditas. Conversos. La expulsión de 1492 y sus consecuencias, ed. A. Alcalá (Valladolid, 1995), 246-268. 
por la liquidación de la judería, sino porque en Nápoles también se ejerció la represión inquisitorial de los judaizantes, como veremos más adelante.

Por otra parte, la configuración inicial de la comunidad de cristianos nuevos del Reino de Nápoles contiene una particularidad que me gustaría subrayar. Me refiero a que sus miembros tenían sus orígenes en los territorios de la Corona de Aragón, lo cual añade un gran interés a su estudio, ya que su trayectoria es mucho menos conocida que la que siguieron castellanos y portugueses.

A partir de 1580, como ocurrió en otros territorios de la monarquía, se produjo la incorporación de los portugueses, facilitada por la anexión de Portugal a los reinos de Felipe II. La comunidad creció y se extendió por el reino, y algunos de sus miembros alcanzaron las más altas posiciones sociales, aunque también un sector padeció la persecución inquisitorial ${ }^{6}$. Tras ese período de sesenta años, el estallido de la sublevación portuguesa en 1640 marcó el inicio de una nueva etapa caracterizada por las grandes turbulencias. En el telón de fondo del nuevo escenario, se proyectaban los sucesos que se producían en los territorios ibéricos y los que afectaban a la mayor parte de Europa, sumida en la guerra de los treinta años, tras la cual, como consecuencia del nuevo orden diseñado en Westfalia, se produjo la recolocación de la judería sefardí ${ }^{7}$. En Castilla, la caída del Conde-Duque de Olivares en 1643, seguida de la sustitución del Inquisidor general fray Antonio de Sotomayor por Diego Arce y Reinoso, más los efectos de la bancarrota de 1647 sobre los hombres de negocios portugueses, tuvieron consecuencias gravísimas sobre la comunidad de cristianos nuevos que habitaba en el reino. En los años cincuenta y sesenta, el Santo Oficio llevó a cabo una campaña de persecución contra los judaizantes que barrió del suelo castellano a la mayor parte de la comunidad. Los procesos de fe impulsaron la última diáspora de los cristianos nuevos ibéricos y su definitiva disolución ${ }^{8}$.

${ }^{6}$ P. SCARAmella, «La campagna contro i giudaizzanti nel Regno di Napoli (15691582): antecedenti e risvolti di un'azione inquisitoriale», en Le Inquisizioni cristiane e gli ebrei. Tavola rotonda nell'ambito della conferenza annuale della ricerca (Roma, 20-21 dicembre 2001) (Roma, 2003), 357-373.

7 J. IsRAel, La judería europea en la era del mercantilismo, 1550-1750 (Madrid, 1992).

${ }^{8}$ Sobre ese proceso y las comunidades afectadas, ver P. HuERga Criado, En la Raya de Portugal (Salamanca, 1994). B. LóPez Belinchón, Honra, Libertad y Hacienda (Alcalá de Henares, 2001). M. Schreiber, Marranen in Madrid, 1600-1670 (Stuttgart, 1994). 
También en el Reino de Nápoles -donde la Inquisición española no operaba- se desarrolló desde finales de los años cincuenta del siglo XVII una campaña represiva contra los judaizantes. Paralelamente a lo que hacían los inquisidores en Castilla, la Congregación del Santo Oficio, presidida por el papa, dirigió desde Roma una serie de procesos de fe abiertos contra los cristianos nuevos afincados en el reino?.

Fueron presentados así:

Essendosi resa sospetta di giudaismo la famiglia portughese habitanti in Napoli e in altri luoghi di quel reyno per alcune denunzie capitate nel tribunale della Santa Inquisitione et in quello del Señor Cardinale Arcivescovo di detta città, si dovrà hora riferire tutto il stato di questa causa et insieme gli inditii che dal anno 1616 sino al presente giorno si sono acumulati ${ }^{10}$.

[...] è una causa gravissima trattandosi anco di un gravissimo male non solo perche si trata d'apostasia dalla cattolica fede, ma perche abbraccia una gran moltitudine di giudaizanti essendone insin'adesso inditiati più di ducento, e questi hanno infettato non solo la città di Napoli ma de essa è diffuso il male in molte città del regno come Salerno, Bitonto, Benevento, Manfredonia et altre, [...] Ecco quanto male há partorito una sola radice di pochi Vargas e Catalani venuti come dicono alcuni da Calabria dalla terra di Senisi benche loro si vantino d'esser descendenti da Spagna $[\ldots]^{11}$.

La primera de las citas se refería particularmente al linaje de los Vaaz, de origen portugués, y la segunda a las familias del círculo de los Vargas,

${ }^{9}$ La historiografía no ha mostrado gran interés por el ejercicio de la inquisición en el Reino de Nápoles desde la obra ya clásica de L. AmabiLE, Il Santo Officio dell'Inquisizione in Napoli (Città di Castello, 1892); G. Romeo, «Una città, due inquisizioni. L'anomalia del Sant'Ufficio a Napoli nel tardo '500», Rivista di Storia e Letteratura religiosa 24 (1988), 42-67; A. DEL Col, L'Inquisizione in Italia (Milano, 2006). No obstante, véase ahora P. A. MAzUR, The Roman Inquisition and the Crypto-Jews of Spanish Naples (15691582) (PhD dissertation, Nortwestern University, 2008), a la que no he tenido acceso durante la elaboración de esta investigación.

${ }^{10}$ Fragmento del sumario, Archivio della Congregazione per la Dottrina della Fede, St. St. BB3b.

${ }^{11}$ Fragmento de la carta de 4 de diciembre de 1662 dirigida a la Congregación del Santo Oficio por fray Serafino Candia, archivero del Santo Oficio en el Reino de Nápoles, ACDF, St. St. BB4d. La documentación que sustenta mi estudio se halla casi exclusivamente en este mismo libro. 
las cuales se vanagloriaban de sus raíces españolas ${ }^{12}$. Ambos grupos familiares eran sospechosos de judaizar, es decir, de ser fieles practicantes de la religión judía a pesar de estar bautizados. Desde el punto de vista de los inquisidores, la extrema gravedad del asunto residía, no solo en la magnitud del delito, pues se trataba de apostasía, sino en el abultado número de delincuentes y en su dispersión territorial, ya que calcularon que los encausados formaban una complicidad de más de doscientas personas residentes en ciertas regiones del reino, además de la capital.

\section{UNA COMUNIDAD EN VÍAS DE DISOLUCIÓN}

Hacia mediados del siglo XVII, los que continuaban siendo identificados como descendientes de los judíos ibéricos, integraban una comunidad en vías de asimilación social, y consecuentemente de disolución, en la que convivían individuos que anhelaban la culminación de ese proceso, situándose en el mismo por delante de los demás, e individuos apegados a la tradición heredada que se resistían a abandonarla; entre unos y otros, se entremezclaban quienes mantenían actitudes intermedias. Las diferentes voluntades no se correspondieron ni con el estatus socioeconómico ni con el género, pues son demasiadas las excepciones que contradicen tales determinismos. Por otra parte, la transición desde la marginalidad a la integración fue un proceso dinámico, protagonizado por sucesivas generaciones y condicionado por circunstancias variables, durante el cual se produjeron avances y retrocesos.

Tal como explicaba el inquisidor de Nápoles en junio de 1660, aquella compleja comunidad estaba formada por dos grandes redes de parentesco: la de los Vaaz y la de los Vargas, a los que se agregaban individuos o familias que mantenían relaciones con ellos, principalmente de dependencia:

\footnotetext{
${ }^{12}$ Ha incluido, revisado y completado la información disponible sobre algunos de los miembros más destacados de la familia Vaaz, G. SABATINI, «Alleati? Nemici? I portoghesi, i genovesi e il controllo del sistema di approvvigionamento e del mercato del credito a Napoli tra XVI e XVII secolo», en Studi storici dedicati a Orazio Cancila, eds. A. GIUFFRIDA et al., Quaderni-Mediterranea. Ricerche storiche 16 (2011) II, 557-588. No disponemos de ningún estudio acerca de los Vargas posterior a la crónica de D. Confuorto, Notizie d'alcune famiglie popolari della Città e del Regno di Napoli. Divenute riguardevoli per causa di ricchezze, o dignità (Napoli, 1693), en Biblioteca Nazionale di Napoli, ms. X A 15.
} 
Sono questi distinti in due classi, l'una delle quali comprende la casa Vaez et altri che con essa hanno connessione, l'altra contiene li Vargas con suoi dependenti e congiunti ${ }^{13}$.

La reconstrucción genealógica demuestra que, en efecto, los Vaaz habían tejido una tupida red de parentesco cuya identidad común residía en el apellido Vaaz. En cambio, el caso de los Vargas era bastante distinto, porque el apellido Vargas lo llevaba una de las familias, pero no las demás, aunque fueran parientes. Los Vargas, los Gaetani, los Barone, los Rossi, Barbuto y otros estaban unidos por los lazos de la sangre, pero no formaban un grupo familiar tan compacto como el de los Vaaz ${ }^{14}$. Entre los Vaaz y el círculo de los Vargas no parece que se hubieran entablado sólidas relaciones, ni familiares ni de otro tipo. Solo conozco un matrimonio, negociaciones fallidas de algún otro y el trato frecuente entre ciertos individuos. Consecuentemente, por el momento no se puede hablar con propiedad de una única comunidad.

Por lo que se refiere a las respectivas estrategias matrimoniales, las de los Vaaz se muestran con bastantes detalles, no así las de los Vargas. Entre estos últimos, queda constancia de matrimonios con miembros de la comunidad, de enlaces consanguíneos, pero también de otros que señalan en la dirección contraria. Faltan datos para valorar sus elecciones conyugales, pero, en todo caso, la tendencia endogámica se percibe mucho más débil que entre los Vaaz (véase árbol genealógico núm. 1).

La primera generación de los Vaaz impuso una endogamia casi absoluta; sin embargo, Simone Vaaz, II conde de Mola y cabeza del linaje, modificó ese criterio y optó por la combinación de dos estrategias opuestas: endogamia para los varones y enlaces exogámicos para las mujeres. Concertó el matrimonio de sus hijas con caballeros napolitanos de reconocido prestigio, destinando una buena parte del patrimonio familiar para las respectivas dotes. Gratia esposó a Marcantonio Muscetola, Anna a Orazio Serzale y Fiorenza a Girolamo Carmignano ${ }^{15}$. En cambio, los que dispuso para los varones se acordaron dentro de la familia. Álvaro casó

\footnotetext{
${ }^{13}$ ACDF, St. St. BB4d.
}

${ }^{14}$ Para no hacer una enumeración engorrosa, en adelante me referiré a todos ellos como el círculo de los Vargas.

${ }^{15}$ Sobre las familias incluidas en los «seggi» y su jerarquía, ver G. GALAsso, Napoli capitale. Identità politica e identità cittadina. Studi e ricerche 1266-1860 (Napoli, 1998). 


\section{Árbol genealógico núm 1. FAMILIA VARGAS}

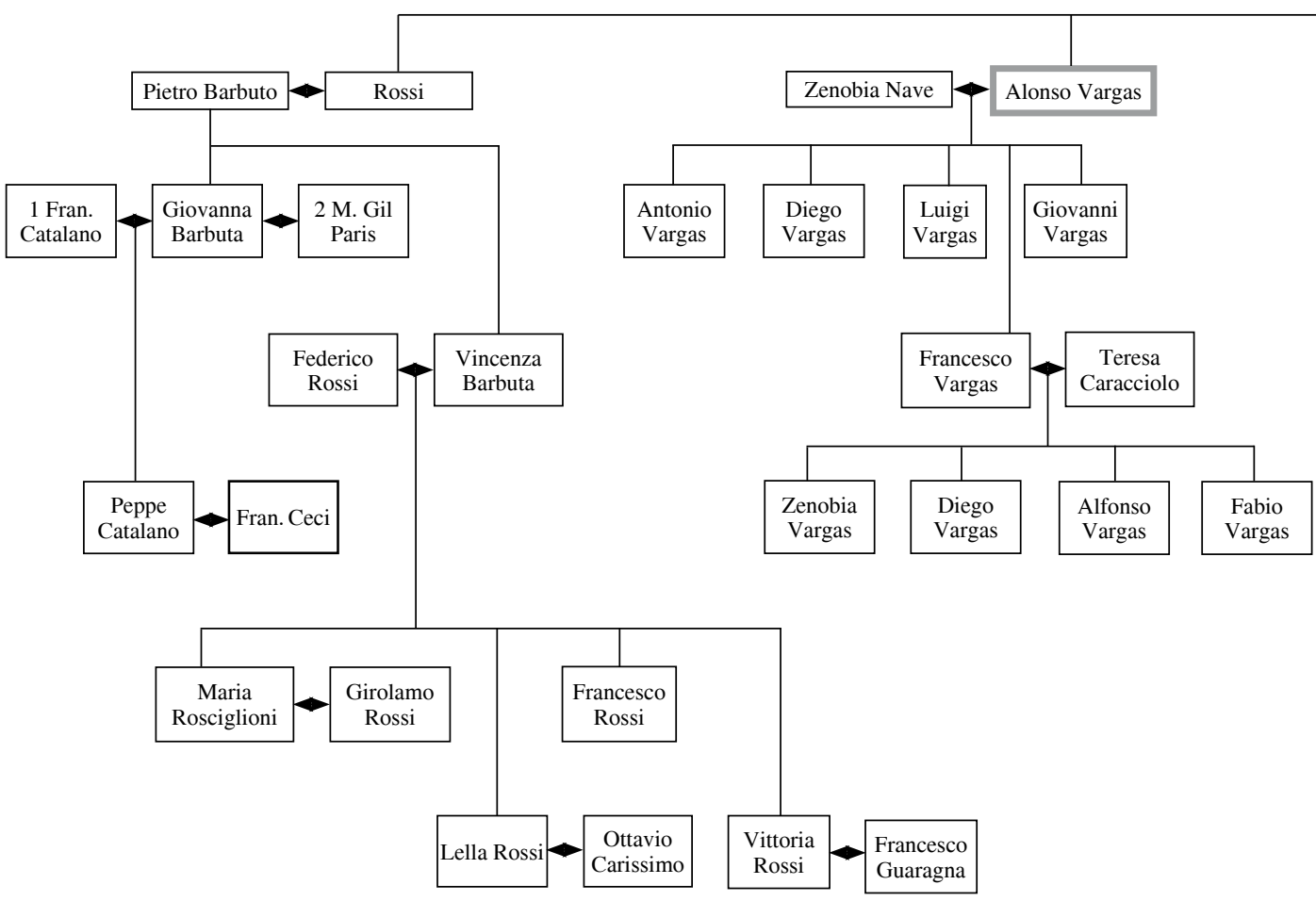




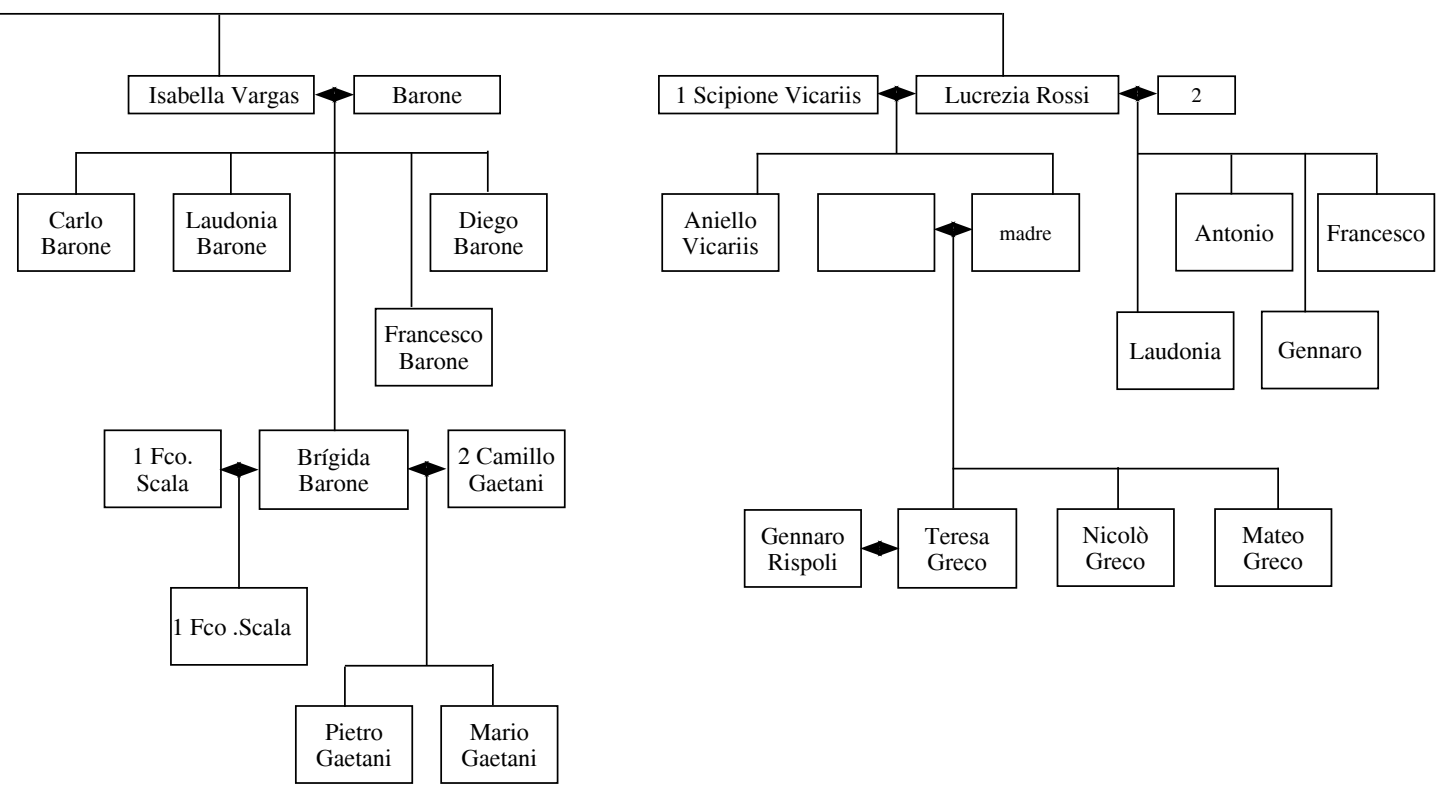


con su prima Iumara y para Odoardo, que sería el III conde de Mola, se eligió a Gratia Vaaz de Andrada, soldando así la unión a la rama familiar de los Vaaz de Andrada y asegurando la sucesión dentro de la propia familia (árbol genealógico núm. 2).

No secundaron esa parcial apertura exogámica los Vaaz de Andrada, con los que habían reforzado sus vínculos en la anterior generación mediante el matrimonio de los cuatro hermanos con tres hermanos de Simone Vaaz y uno de sus primos. La rama de los Andrada continuó acordando enlaces consanguíneos, entre los que destacó el de los primos hermanos Emanuele y Fiorenza, él heredero del barón de Campomarino y ella heredera del duque de San Donato. Solo abrieron la puerta a la exogamia para dos de las mujeres, pero en una dirección muy distinta a la que seguía Simone Vaaz para sus hijas, porque en lugar de caballeros napolitanos de conocida estirpe, sus esposos eran miembros de la comunidad marránica portuguesa (árbol genealógico núm. 3).

Fuera de los Vaaz y los Vargas, pero alrededor de ellos, se prolongaba la comunidad, mostrándose más heterogénea de lo que a primera vista parece. Al desplegar la trama que articulaba a sus miembros, se observa que en ella eran parte principal, pero no única, las redes de parentesco de los Vaaz y los Vargas; porque existían núcleos no vinculados por los lazos de la sangre ni a unos ni a otros y que, sin embargo, llenaban un espacio y mantenían relaciones de diversa índole con ellos. Se trataba de personas que ocupaban posiciones subordinadas, bien porque estaban a su servicio personal, o bien porque mantenían con ellos algún tipo de relación de dependencia. Algunos de estos, desde su baja posición, sobresalen por haber sido miembros muy activos de la comunidad, especialmente en cuanto se refería a la práctica religiosa en la clandestinidad.

El conjunto se articulaba mediante una estructura jerarquizada en la que grupos e individuos desiguales mantenían entre sí diversas relaciones de intercambio. Desde abajo -donde se movían los criados y los que vivían gracias a la caridad de otros a cambio de algunos servicios- ascendiendo a las casas en las que se vivía con cierta comodidad, y de ellas a los que disfrutaban de algunos lujos, hasta alcanzar el espacio exclusivo de los privilegiados. No componían, por lo tanto, un grupo homogéneo, por mucho que los más ricos y poderosos proyectaran una sombra que ocultaba al resto. 
A las redes familiares de los Vaaz y los Vargas pertenecían personas muy notorias de la sociedad napolitana que habían conseguido su inclusión en el estamento de los poderosos del reino gracias a la posesión de tres atributos: posesiones feudales, títulos de nobleza y puestos preeminentes en la magistratura. Dentro de la red familiar de los Vargas, destacaban Giovanni Vargas y su primo hermano Antonio Solimene, marqués de la Guardia. Giovanni ocupó ese lugar central por haber sobrevivido a su hermano mayor Francesco, que llevó los títulos de príncipe de Carpino y duque de Cagnano, obtenidos por su padre el consejero Alonso Vargas sobre dichas propiedades ${ }^{16}$.

En el linaje de los Vaaz sobresalían dos figuras: la de Odoardo Vaaz, III conde de Mola y duque de Casamassima, y la de Emanuele Vaaz de Andrada, barón de Campomarino y duque de San Donato, primos hermanos y cuñados entre sí. Ellos pertenecían a la tercera generación de los Vaaz en el reino napolitano, y habían heredado el patrimonio acumulado por las dos anteriores. La mayor parte se lo debían a Miguel Vaaz, un potente hombre de negocios nacido en Portugal que labró una gran fortuna en Nápoles. A la hora de su muerte, declaró que poseía 240.000 ducados de capital en joyas, mercancías, deudores y otras cosas, y que su renta anual se cifraba en 23.000 ducados. Transmitió a sus herederos feudos y títulos de nobleza: Belrisguardo, situado en la provincia de Principato Citra, fue su primera adquisición, efectuada en 1597; en 1609 compró Casamassima, San Nicandro y Rutigliano, en provincia de Bari; a continuación, el feudo de San Donato en Terra d'Otranto, y en 1612 obtuvo el consentimiento regio para la adquisición de Mola de Bari, con los derechos del puerto y de la aduana. Esta última sería la posesión sobre la que logró el primer título de nobleza para él y sus descendientes. Un año después de la compra, en 1613, le fue otorgado el título de conde de Mola ${ }^{17}$. Simone, su sobrino y heredero, consiguió para su primogénito el título de duque de Casamassima y su primo Michele Vaaz de Andrada ostentó

\footnotetext{
${ }^{16}$ Confuorto, Notizie d'alcune famiglie.

${ }^{17}$ Fuentes documentales en C. BeLLI, «Michele Vaaz hombre de negocios», en Ricerche sul '600 napoletano. Saggi e documenti per la storia dell'arte (Milano, 1990), 7-42; G. Coniglio, Il viceregno di Napoli nel sec. XVII (Roma, 1955); I. ENcISo, Linaje, poder y cultura. El virreinato de Nápoles a comienzos del siglo XVII. Pedro Fernández de Castro, VII conde de Lemos (Madrid, 2007); SABATINI, «Alleati? Nemici? I portoghesi», 19.
} 


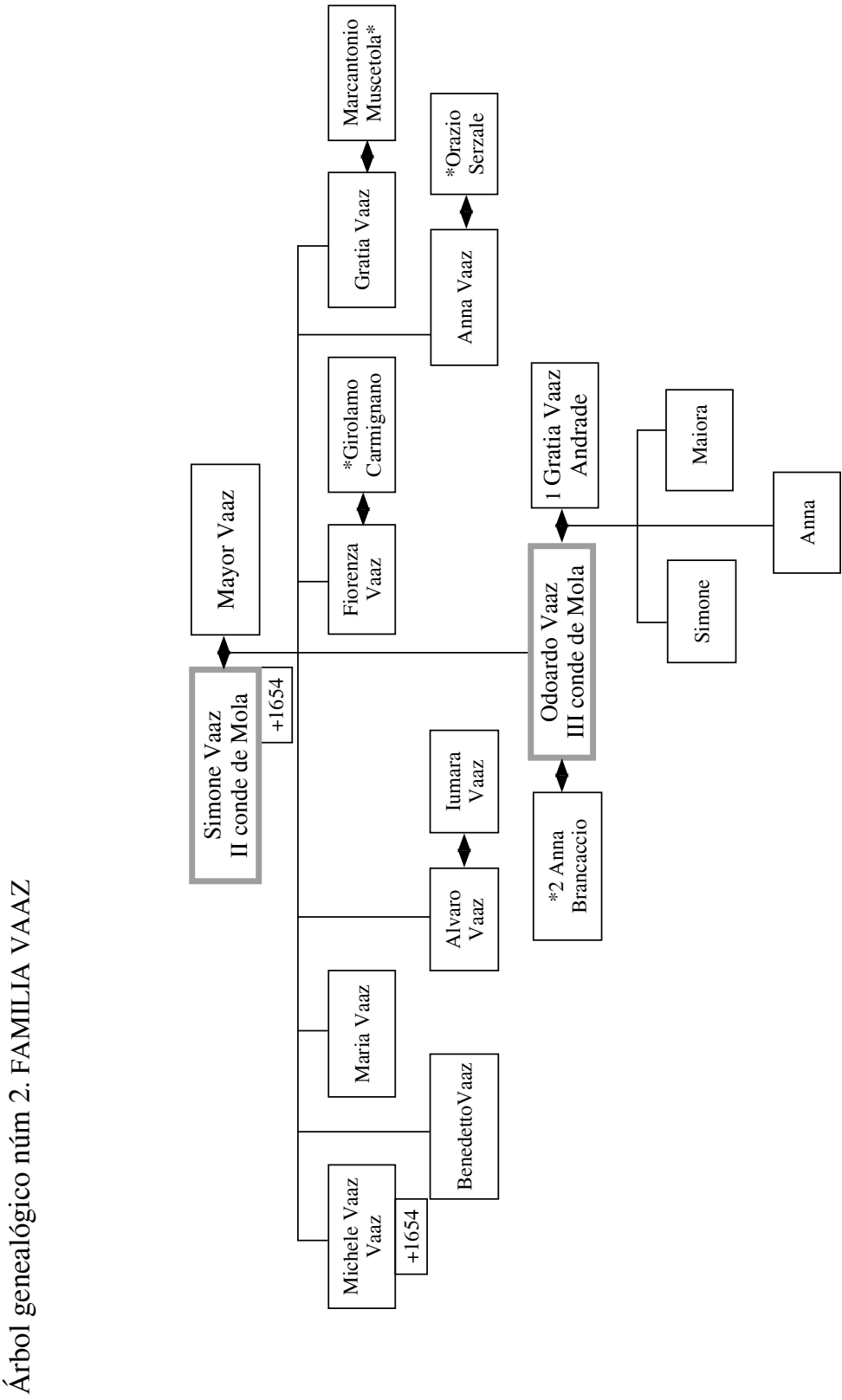

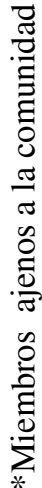

SEFARAD, vol. 72:2, julio-diciembre 2012, págs. 351-387. ISSN: 00037-0894. doi: 10.3989/sefarad.012.011 


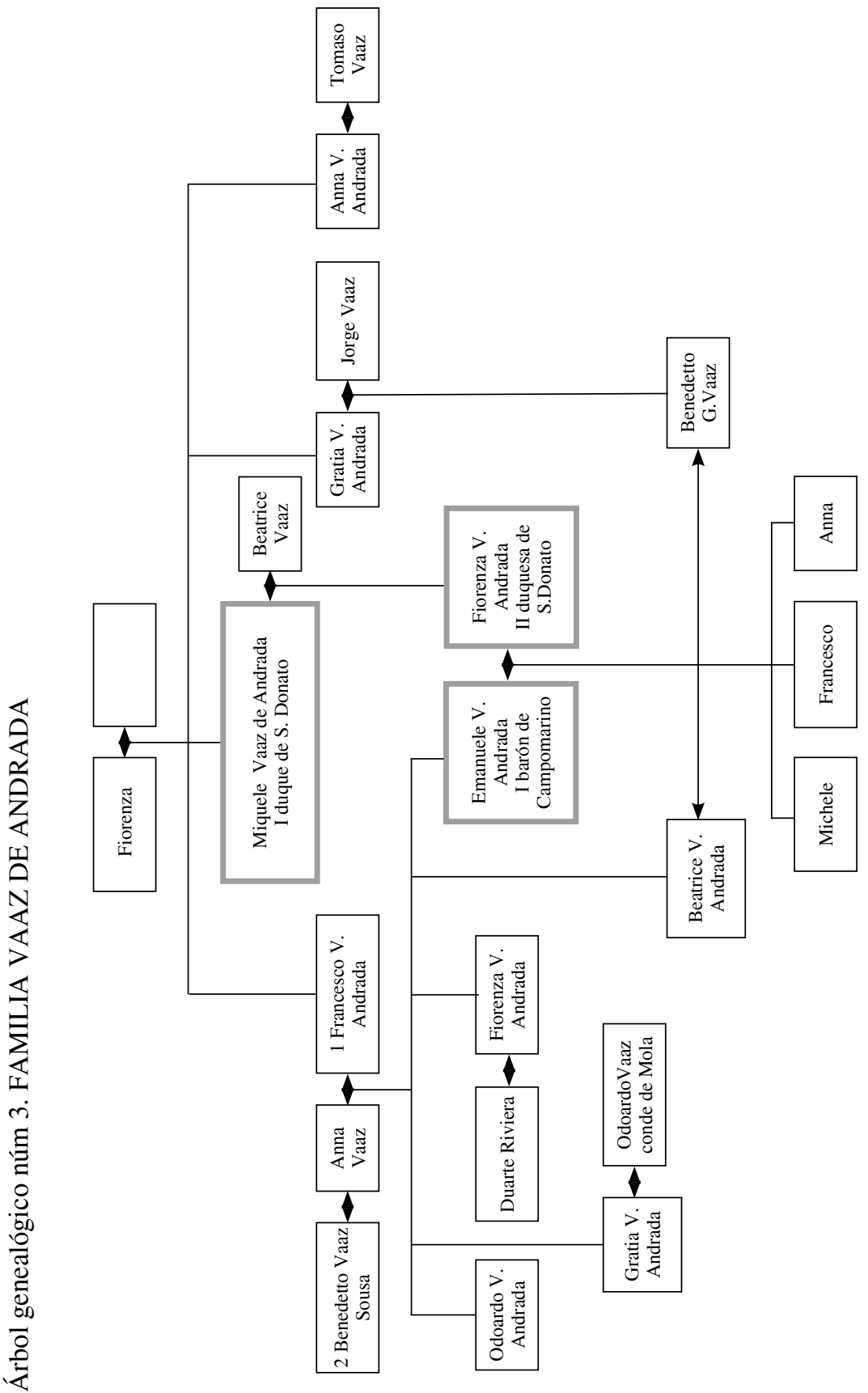

SEFARAD, vol. 72:2, julio-diciembre 2012, págs. 351-387. ISSN: 00037-0894. doi: 10.3989/sefarad.012.011 
el de duque de San Donato. Un hermano de éste, Francesco, fue barón de Campomarino ${ }^{18}$. En cambio, la tercera generación no hizo crecer las posesiones feudales ni obtuvo nuevos títulos de nobleza, pero sí afianzó su inclusión en la oligarquía por la vía del matrimonio. Recordemos que tres de las hijas de Simone Vaaz se esposaron con tres hombres nacidos en las familias de los notables napolitanos.

A mediados del siglo XVII, esas familias habían recorrido un camino que las conducía hacia la plena integración en la sociedad en la que vivían. Los beneficios obtenidos con las empresas mercantiles y financieras que habían tenido entre manos los habían invertido en propiedades feudales y en títulos de nobleza, es decir, bienes raíces y honores que los equiparaban a los antiguos linajes del reino. Y para completar ese recorrido de inclusión y encumbramiento social, tomaron la decisión de apuntalar su poder ocupando puestos relevantes en la magistratura. Alonso Vargas había sido juez in civilis en la Magna Corte di Vicaria, como su contemporáneo Simone Vaaz. Vargas llegó a ser consejero del Sacro Regio Consiglio y Vaaz obtuvo el nombramiento de presidente de la Regia Camera della Summaria. Por otra parte, la trayectoria política de Simone Vaaz culminó en 1653, al final de su vida, cuando fue nombrado por Felipe IV regente en el Consiglio Collaterale, máximo órgano político del reino con el que gobernaba el virrey. El hijo de este, Odoardo Vaaz, desde 1643 ejerció como juez in criminalibus en el tribunal de Vicaria hasta que fue procesado. Asimismo, habían estudiado leyes y se identificaban profesionalmente en ese campo algunos de los miembros del círculo de los Vargas ${ }^{19}$.

Riqueza, poder y honores no bastaban. Por eso, hicieron lo posible para que se los reconociera como fieles cristianos, para que su origen no los

${ }^{18}$ M. SIRAGo, «L'inserimento di una famiglia ebraica portoghese nella feudalità meridionale. I Vaaz a Mola di Bari (circa 1580-1816)», Archivio Storico Pugliese 40 (1987), 119-158.

${ }^{19}$ Sobre Alonso de Vargas: nombramientos sucesivos como Giud. MCV in civ.: Archivio di Stato di Napoli [en lo sucesivo, ASN], OV.9, 11, 12; nombramiento de consejero del SRC: Archivo General de Simancas, SP. 173, 200 y 191, 21 y ASN, Osm.9, 105v-108. Sobre Simone Vaaz, nombramiento como Giud. MCV in civ.: ASN, OV. 13; nombramiento como presidente RCS.: AGS, SP. 178, 175 y ASN, Osm. 4, 46v-49r; nombramiento en el Collaterale: AGS, SP. 212, 12 y ASN, Osm. 22, 96v-99v. Sobre Odoardo Vaaz, nombramiento Giud. MCV in crim.: N. TopPI, De origine tribunalium urbis Neapolis (Napoli, 1666), vol. III, 66-70. 
identificara colectivamente y los encerrara dentro de un espacio social. Así que, al menos exteriormente, y con desigual agrado, reproducían los comportamientos que contemplaban en su entorno. Hicieron visible su cumplimiento de las leyes de la iglesia asistiendo a las celebraciones religiosas, adornaron sus casas con imágenes y cuadros religiosos, dieron educación cristiana a sus hijos. Incluso gastaron su dinero en obras piadosas. La más llamativa la llevó a cabo Miguel Vaaz, el fundador de su linaje en Nápoles, que hizo construir una iglesia que puso bajo la advocación del arcángel de su mismo nombre, San Miguel, donde colocó el panteón familiar ${ }^{20}$.

A mediados del siglo XVII, a pesar de los éxitos obtenidos por las generaciones anteriores, cuya herencia habían recibido, y a pesar de los pasos dados hacia la plena integración social, aún no habían concluido ese proceso, lo cual dejaba al descubierto una brecha por la que podía introducirse el Santo Oficio. Y así fue. El modo en que se produjo la intervención de los inquisidores revela que todavía eran vulnerables, y que su principal debilidad residía en las tensiones y conflictos internos que padecían. Si bien es obvio que las víctimas de los procesos de fe se hallaron dentro de la comunidad, también es cierto que de la misma salieron los delatores. No fueron las acusaciones procedentes de personas ajenas a la comunidad las que provocaron la represión religiosa, sino que esta se produjo aprovechando los conflictos internos de aquella comunidad en vías de disolución. Los inquisidores sacaron a la luz todas sus contradicciones y las utilizaron para ejercer su misión.

Desde 1616, cuando se recogieron las primeras testificaciones de judaísmo, las que se produjeron durante las cuatro décadas siguientes fueron escasas y dispersas, y casi todas vertidas por criadas que habían estado o estaban al servicio de los denunciados. Fueron sucesivamente archivadas por los inquisidores y, por lo tanto, no tuvieron consecuencias inmediatas. En cambio, en la década de los años cincuenta, los delatores surgieron de la propia familia, comparecieron sin haber sido llamados para acusar a muchos de sus parientes de judaizar en secreto, por lo que sus testimonios tuvieron un peso y un alcance mucho mayor, hasta el punto de haber sido considerados suficientes para iniciar la investigación ${ }^{21}$.

\footnotetext{
${ }^{20}$ BELLI, «Michele Vaaz hombre de negocios», 22-25.

${ }^{21}$ Adoptaron la figura del malsín, sobre la que trató J. CARo BAROJA, Los judíos en la España moderna y contemporánea (Madrid, 1978²), vol. I, 295-302.
} 
Los primeros delatores se llamaban Fiorenza Vaaz y Cesare Roberti. Fiorenza era hija de Jorge Vaaz y Gratia Vaaz de Andrada y prima en segundo grado del conde de Mola. Había conseguido curarse de la peste gracias a las atenciones del barbero Francesco Campagna, de quien se enamoró y con quien decidió casarse, a pesar de la oposición de su familia. Nueve meses después de haber abandonado la casa en la que había vivido hasta entonces, junto a su hermano Benedetto y su cuñada Beatrice, sus relaciones no habían hecho más que empeorar. Acudió entonces al santo oficio, dispuesta a revelar lo que conocía desde mucho tiempo atrás, cuando todavía vivían sus padres. Su declaración describía una familia dividida, en la que solo su hermano Benedetto había seguido las enseñanzas de su madre, que era una sevillana que había practicado los ritos mosaicos durante toda su vida en Nápoles. Fuera del propio núcleo familiar, lanzó las mismas acusaciones, entre otros, contra su primo Odoardo, el conde de Mola, en cuya casa había pasado una larga temporada tiempo atrás.

Cesare Roberti había precedido a Fiorenza en su comparecencia ante los jueces de la fe. Ya un año antes de la peste había delatado a muchos de los parientes de su mujer, Isabella Vaaz de Sousa, ante el padre Angelo Maria Verricelli. Entonces contó que a los pocos días de casarse empezó a sospechar que su mujer judaizaba, porque veía que el sábado no hacía sus tareas como los demás días y que no comía el queso junto a la carne. Le preguntó directamente si era judía y ella le respondió tranquilamente, con una sonrisa, que sí, que ella seguía la ley mosaica desde los siete años como su madre le había enseñado y como la seguían sus hermanos, sus tíos y otros parientes, entre los que se encontraban el duque de San Donato y su esposa, así como Gratia, la mujer del conde de Mola, quienes solían reunirse en la casa de Fiorenza y Duarte de Riviera para celebrar juntos los ayunos.

La confianza con que Isabella habló a su marido, probablemente se debería a que, al considerarle un miembro más de la misma comunidad, no esperaría que reaccionase como lo hizo, exigiéndole que renunciase a todas aquellas creencias; y mucho menos temería que fuera a delatarlos ante el Santo Oficio. A partir de entonces, Isabella fingió ante su marido, que se empleó en persuadirla de que abandonara los ritos judaicos y se comportara como una buena cristiana. 
Roberti mostró su satisfacción porque creyó que su mujer había comprendido que había sido engañada por aquella perversa secta, de manera que la excluyó de la denuncia y prosiguió dando los nombres de los familiares más cercanos de Isabella, es decir, el de su madre y los hijos que había tenido con su primer marido, de los que ella le había asegurado que compartían la misma fe, no así del padre de ella al que Roberti consideraba tan buen cristiano como él mismo. La culpa recaía en el grupo familiar formado por la madre, a la que responsabilizaba del adoctrinamiento de Isabella y de todos sus hijos. Y para concluir, extendió la sospecha a todo el linaje Vaaz, añadiendo:

È fama publica e divulgata per tutta la città di Napoli et há inteso infinite volte che quelli della famiglia Vaaz hebraizano, non solo per esser portughesi ma per molti altri inditii dati da loro diverse volte, quasi tutti habbitano in Napoli á Pizzofalcone et è facile á saper dove habitano essendo persone assai note ${ }^{22}$.

Parece que consideraba que al delatarlos no hacía sino poner en manos del Santo Oficio el testimonio que confirmaba lo que se comentaba en la calle.

Al final de sus días, postrado en el lecho de muerte, Roberti recibió la visita del nuncio, que había acudido a su casa para interrogarle después de haber oído la delación de Fiorenza. El moribundo le confió las sospechas que tenía de que su mujer siguiera vinculada a la complicidad de judaizantes, por lo que había incluido en su testamento la recomendación de que volviera a casarse, pero que no lo hiciera con ningún pariente, ni de ella ni de él, hasta el décimo grado. En el caso de que cumpliese su voluntad, la nombraba heredera universal, pero si hiciese lo contrario sólo le quedaría su dote con el letto vedovile et antifato.

En ambos casos, el núcleo familiar se presenta dividido por la creencia religiosa, pero los motivos por los que Cesare y Fiorenza actuaron como lo hicieron parecen muy diferentes. Si en el caso de ella se vislumbra ese impulso que empujaba a buscar en el tribunal de la fe el medio para resolver un grave enfrentamiento familiar, en el de él todo apunta a que fue la voluntad de romper absolutamente con la comunidad marránica en la que había nacido lo que le movió a delatar.

\footnotetext{
${ }^{22}$ Archivio Storico Diocesano di Napoli, Sant'Ufficio 153.1921.
} 
Tanto Cesare como Fiorenza habían nacido y se habían educado en una familia de cristianos nuevos, pero en algún momento de su vida habían tomado la decisión de desligarse de la complicidad religiosa e incluso de romper con la solidaridad familiar. No era el caso de Antonio Suárez Coronel y Aniello di Vicariis, quienes formaban parte de esa complicidad. No comparecieron espontáneamente sino que fueron convocados por estar implicados en un asunto de tratos con la judería livornesa. Confesaron su culpa y la de muchos más, proporcionando a los inquisidores una información bastante más amplia y valiosa que la que habían obtenido hasta entonces. Coronel era pariente de los Vaaz y Vicariis lo era de los Vargas, cuyo apellido se incluyó en la investigación por primera vez. No es de extrañar la preocupación que en todos causó la prisión de Aniello di Vicariis, porque como escribió el inquisidor a la Congregación:

[...] questo Aniello non fa altro che piangere a segno, che l'abbondanza delle lagrime e frequenza dei singhiozzi molte volte gli impediscono il proferire le parole. Che mostra un pentimento non ordinario, aspetta con impatienza l'assolutione, e di continuo essamina la propria conscienza per fare una confessione generale e che quando vi conconrra la Sacra Congregatione si esibisce pronto a procurar che il fratello qual si ritrova in Livorno venga in Napoli a riconoscer le proprie colpe $[\ldots]^{23}$.

Las dos declaraciones cruzaron las culpas entre ambas redes familiares, mostrando así sus relaciones y exponiéndolos unidos por el delito colectivo. Asimismo, al ampliar los testimonios que anteriormente se habían vertido, distribuyeron la culpa y extendieron el miedo, el cual, a su vez, impulsó a otros a confesar sobre sí mismos y sobre los demás.

El conde de Mola y su hermano Benedetto, estando presos en la cárcel de Roma, debían estar al corriente de lo que estaba sucediendo, de cómo se iba estrechando el cerco en torno a todo su linaje y a la comunidad en su conjunto. Y parece que también supieron que varios miembros del círculo de los Vargas habían sido trasladados a la cárcel inquisitorial de Roma desde Nápoles. Quizás por eso se decidieron a admitir su culpabilidad, que habían negado reiteradamente hasta la audiencia que se les concedió el 21 de marzo de 1660. Sus confesiones nutrieron la información

\footnotetext{
${ }^{23}$ ACDF, St. St. BB 4d.
} 
acerca de ellos mismos, de sus cómplices, y también de otros judaizantes a los que en algún caso solo conocían indirectamente. En consecuencia, sus hermanas se apresuraron a presentarse ante el inquisidor en Nápoles antes de que las llamara. Viéndose sin más salida, otros las siguieron, desencadenándose así una larga serie de declaraciones espontáneas que se usaron para la apertura de nuevos procesos. Todo ese alud de confesiones de judaísmo recayó, a su vez, sobre los presos en Roma, agravando sus causas, que se concluyeron al cabo de pocos meses. Progresivamente se definía la articulación de esa misma red de complicidad religiosa que traspasaba el marco del parentesco y cruzaba el espacio de solidaridad de un extremo a otro de los grupos familiares.

En los márgenes de ambos grupos familiares, se desenvolvieron dos hombres cuya misma existencia, al quedar desvelada, dejaba a la intemperie la comunidad marránica. Eran Tomaso Ulloa y Francesco Bianco, cuya humilde condición al servicio de los más afortunados los colocaba en una posición central que les había permitido conocer a la mayor parte de los procesados; asimismo, a través de ellos, unos tenían conocimiento de los demás. Ulloa y Bianco iban y venían de una casa a otra, prestando pequeños servicios de todo tipo, incluidos los de índole religiosa, lo cual les otorgaba una posición clave en la supervivencia de la complicidad clandestina. Los que habían testificado en su contra habían coincidido en señalarlos como grandes conocedores de «la Ley» y sus preceptos. Los inquisidores los calificaron de seductores y maestros del judaísmo. Lo que Francesco Bianco sabía de muchos de ellos no lo pudo declarar porque falleció a causa de la peste, pero su hijo Giuseppe transmitió al nuncio lo que su padre le había contado. Y la prueba definitiva la proporcionó el propio Ulloa cuando su cuerpo fue examinado en la cárcel de Roma por dos neófitos que afirmaron que estaba circuncidado.

Por último, entre los muchos servidores de los que dispusieron las familias acomodadas, algunos compartieron con sus amos ritos y ceremonias de la fe clandestina. Fueron testigos permanentes de lo que ocurría en los hogares, podían presenciar las prácticas religiosas prohibidas sin que sus señores disimularan, como hacían con el resto de los sirvientes. Por ello, confesiones como la de la criada Giustina Gratiana, en la que reiteraba y añadía detalles acerca del cumplimiento de los preceptos mosaicos, contribuyeron a extender y a agravar las culpas. 
Hasta aquí, todos los nombrados formaban parte de la comunidad aunque no todos participaran en la complicidad religiosa. Con sus testimonios se construyó la mayor parte de los procesos, siendo mínima la contribución de los testigos ajenos a ese mundo, porque fueron pocos los interrogados y menos los que acudieron por su propia voluntad, y lo que contaron, por otra parte, no revelaba gran cosa. Entre ellos, por su mayor sustancia, destacaron las criadas. Viola Imperati, que servía desde hacía trece años en casa del conde de Mola, se presentó sin haber sido llamada para contar lo que durante ese tiempo había presenciado en aquella casa, como que doña Fiorenza, la hermana del conde, no trabajaba los sábados como hacía el resto de los días y se justificaba diciendo que lo hacía por devoción de la santísima virgen. También había visto que sus amos guardaban con mucho cuidado en un escritorio un librito de oficios con el cual leían algunas devociones mientras se paseaban. Y aunque podían oír la misa en su propia casa, sin embargo, a la menor ocasión no acudían, aun siendo día festivo.

No sabemos si había tomado aquella decisión tan grave contra sus amos porque así se lo ordenaba su conciencia de buena cristiana, porque alguien la había instigado a hacerlo, o quizás porque había dejado de servirlos y tenía razones para desearles algún daño. Testimonios anteriores al suyo, que también salieron de boca de unas criadas, aseguraron que no las movía el odio ni el deseo de venganza, sino la propia conciencia atizada por el confesor. Como explicó una de ellas, se había presentado,

[...] perche confessando con il P. D. Angelo Maria Vericelli teatino in S. Maria degli Angeli mi há detto che io sono obligata deponerla al santo officio e perciò l'hó deposta ${ }^{24}$.

Fuera de ese ámbito, fueron muy pocos los que acudieron a testificar, pero algunos hubo, porque las voces corrían y animaban a quienes el comportamiento sospechoso de amigos o conocidos nunca hasta entonces los había impulsado a denunciar. Fue el caso de doña Vittoria Severina, marquesa della Ripa, que habló de los extraños hábitos de su difunta amiga la señora Lella, como familiarmente se llamaba a Angela Rossi. Pero ese comportamiento fue más bien excepcional y de escasas consecuencias, sobre todo en comparación con la rotundidad del apoyo a los procesados por parte de las familias con las que habían emparentado.

${ }^{24}$ ASDN, Sant'Ufficio 153.1921. 
El ingreso en la nobleza del reino de un sector de la comunidad de cristianos nuevos se había producido a través de los matrimonios concertados con las casas aristocráticas y del reconocimiento regio en forma de títulos nobiliarios. Lograron encumbrarse al final de un recorrido que no estuvo exento de dificultades. Además de las tensiones internas, generadas en el seno de la comunidad, tuvieron que vencer los obstáculos y pasar los filtros que entorpecían el ascenso social ${ }^{25}$. Sin embargo, los conflictos, enemistades, rivalidades con otras familias de la oligarquía, no se manifestaron cuando el Santo Oficio los acorraló colocándolos en una situación de enorme vulnerabilidad. Aunque se brindaba a los enemigos una ocasión tan propicia para la venganza, para el ajuste de cuentas, estos no se produjeron, y si hubo algún intento, fue más bien anecdótico. Aun suponiendo la implicación de algún instigador detrás de ciertas testificaciones en su contra, fue mucho más influyente la intervención a su favor de los miembros de la oligarquía napolitana con los que compartían intereses. Esos notables, a quienes se atribuían los valores dominantes, antes que comprometerse con la inquisición y su ofensiva, optaron por la defensa de los intereses estamentales de sus linajes.

Desde el comienzo, hubo quienes trataron de abortar los procesos, entre ellos Girolamo Carmignano, que se desplazó a Roma con el propósito de intervenir de alguna forma a favor de su cuñado, el conde de Mola. También en Nápoles estaba usando promesas y amenazas para arruinar las causas, y no era el único. Más adelante, cuando el conde de Mola y su hermano ya habían confesado, el abogado de los reos presentó a la Congregación un escrito de defensa en el que exponía con toda claridad la inquietud que los procesos habían sembrado entre algunas de las casas principales de Nápoles, señalando las consecuencias negativas que tendría una sentencia rigurosa

[...] per esser egli imparentato con molti personaggi e case grandi napoletane alle quali ridondarebbe in dishonore la di lui condanna; e di questi ha data nota il Giordani, asserendo essere il Cardinale Brancaccio, l'Arcivescovo di Chieti, Vescovo d'Avellino, il Cavaliere Brancaccio Generale dell'Artigliaria, il Duca di Cancellara di casa

${ }^{25}$ Sobre ese proceso, es de gran interés el paralelismo con los genoveses, y simultáneamente la competencia entre ambos grupos, analizados por SABATINI, «Alleati? Nemici? I portoghesi», 1-13. 
Caraffa, D. Giuseppe et Annibale Brancaccio, D. Giovanni Origlia, Fabritio Minutoli, il Duca di Monteleone, il Duca di Belguardo di casa Pignatelli, il Principe di Marsico di casa Caraccioli, il Principe di Bresici di casa Bartirotti d'Aragona, il Duca di Belcastro di casa Sersale, il Duca di Spezzano Muscetola, Il Marchese di Polignano Radolovichi e D. Girolamo Carmignano ${ }^{26}$.

El argumento del abogado se vio reforzado poco después por el propio inquisidor Piazza en la carta en la cual comunicaba la gran preocupación de las familias por la sentencia que estaba a punto de pronunciarse:

[...] Non debbo però tralasciare di fare sapere come da questi signori di casa Brancaccia mi è stata fatta caldissima istanza perché il Conte di Mola, con cui hanno contratto per loro disgratia strettissima parentela, non venga punito con alcuna penitenza publica, dalla quale possa risultare pregiudizio alle loro famiglie, per il que raccomandano con ogni maggiore ardore alla somma pietà di cotesto Santo Tribunale [...].

La pervivencia de una comunidad de cristianos nuevos en el Reino de Nápoles durante más de un siglo, se revela sin ningún género de dudas como una realidad histórica. Su conciencia colectiva y su apego a la tradición judía son manifiestos, pero también su progresiva descomposición. Paralelamente, se pone de manifiesto la responsabilidad de la iglesia, y especialmente de su brazo inquisitorial, en la creación de la identidad de los cristianos nuevos y en su mantenimiento a lo largo de tanto tiempo, obstaculizando con ello su plena integración en la sociedad cristiana.

\section{LOS PROCESOS DE FE}

En el Reino de Nápoles no se instituyó un tribunal del Santo Oficio que formara parte de la red que se extendía a la mayor parte de las posesiones de la Monarquía Hispánica, incluidas Sicilia y Cerdeña ${ }^{27}$. Como

${ }^{26} \mathrm{ACDF}$, St. St. BB 4d.

${ }^{27}$ Hubo sucesivos intentos por parte de la monarquía de extender al reino de Nápoles el modelo español de tribunal inquisitorial. L. Amabile, Il Santo Officio dell'Inquisizione. Han sido posteriormente analizados en un contexto más amplio por C. J. Hernando, Castilla y Nápoles en el siglo XVI. El virrey Pedro de Toledo (Salamanca, 1994), 304-339; 
en el resto de los dominios de la Iglesia Católica, la represión de la herejía formaba parte de las competencias de los obispos, que la ejercían en sus diócesis a través de sus respectivos vicarios. Simultáneamente, desde 1585, actuaba en Nápoles un ministro que ejercía como inquisidor por delegación directa de la Congregazione del Sant'Uffizio ${ }^{28}$. Ambas instancias judiciales procedían bajo la suprema autoridad de dicha Congregación, que había sido creada en 1542, y que estaba formada por seis cardenales presididos por el papa ${ }^{29}$. Para asegurarse el control efectivo de la jurisdicción inquisitorial en el reino, la Congregación romana se sirvió también del propio nuncio, que suministraba información y transmitía sus mandatos a los inquisidores. Incluso, de modo extraordinario, como veremos a continuación, el nuncio asumió las competencias del inquisidor delegado por decisión de los cardenales.

Entre 1643 y 1656, ejerció como inquisidor delegado en el Reino de Nápoles monseñor Felice Tamburello, que antes había presidido el tribunal arzobispal como vicario de la diócesis ${ }^{30}$. Durante su ejercicio y en los años precedentes, tanto el inquisidor delegado como los vicarios de las diócesis recibieron testificaciones de judaísmo y procedieron al respecto siguiendo las indicaciones de Roma. En 1636, cuando ejercía como inquisidor delegado monseñor Ricciullo, tuvieron lugar ciertos acontecimientos que relacionaban a algunos de los miembros de la familia Vaaz con creencias judaicas. El ministro, una vez realizadas las averiguaciones que la propia Congregación le había indicado, informó de las mismas. Aseguró que los denunciados tenían imágenes religiosas en su casa, que acudían a la iglesia, y que comían tocino, salchicha y demás productos del cerdo,

IDEM, El reino de Nápoles en el Imperio de Carlos V: La consolidación de la conquista (Madrid, 2001), 153-179. M. Rivero, «La Inquisición española en Sicilia (siglos XVI a XVIII)», en Historia de la Inquisición en España y América. III. Temas y problemas, J. Pérez Villanueva y B. Escandell Bonet, dirs. (Madrid, 2000), 1031-1222.

${ }^{28}$ Sobre las delegaciones realizadas por la Congregación entre 1553 y 1585 , ha realizado importantes precisiones G. RoMEO, «Una città, due inquisizioni. L'anomalia del Sant’Ufficio a Napoli nel tardo ‘500», Rivista di Storia e Letteratura religiosa 24 (1988), 42-67.

${ }^{29}$ A. Borromeo, «Congregazione del Sant'Uffizio», en Dizionario storico dell'Inquisizione, dir. A. Prosperi (Pisa, 2010), vol. I, 389-391. Asimismo, A. Prosperi, «Inquisizione romana», en Dizionario storico dell'Inquisizione, vol. II, 815-827.

${ }^{30}$ Amabile, Il Santo Officio dell'Inquisizione, 39. 
o sea que daban muestras de comportarse como auténticos cristianos; sin embargo -añadía-

questa casa era comunmente tenuta ebrea, ma non trovava altra ragione di questa opinione se non quella dell'origine portughese ${ }^{31}$.

El asunto se cerró sin más consecuencias.

Igualmente, la Congregación tuvo conocimiento de las testificaciones que fueron recogiendo los tribunales episcopales, pues cada vez que se produjeron fue informada e intervino en el procedimiento. Las primeras se remontaban a 1616 y se referían a Miguel Vaaz, ya por entonces conde de Mola, y a su familia. Habían comparecido ante el fiscal del arzobispado cinco mujeres que aseguraron que aquellos señores en la intimidad del hogar observaban la Ley de Moisés. La Congregación consideró que lo más oportuno era dictar el sobreseimiento de la causa hasta el cambio de virrey, ya que el acusado tenía gran aderenza con el conde de Lemos ${ }^{32}$. El cambio esperado estaba muy próximo, pues acabando el verano de ese mismo año, el duque de Osuna hizo su entrada en Nápoles. Efectivamente, la posición de Miguel Vaaz en la corte virreinal varió hasta tal punto que se vio obligado a refugiarse durante tres años en el convento de los padres celestinos para evitar la prisión ${ }^{33}$; sin embargo, la causa no se reabrió.

Diez años después de aquellas denuncias, llegó una desde el obispado de Molfetta, en tierra de Bari, que señalaba a la familia Vaaz de Andrada. La Congregación, tras ordenar al obispo que examinase a algunos testigos, dispuso que no siguiese adelante. Y pasaron veinte años sin que la justicia eclesiástica recibiera ninguna acusación contra los Vaaz, hasta que entre septiembre de 1647 y agosto de 1648 se registraron las testificaciones de tres de las criadas de Anna Vaaz y su hija Beatrice ante Joseph de Januario, que actuaba por delegación del arzobispo Filomarino. Las tres mujeres habían acudido instigadas por sus confesores respectivos, que simultáneamente ejercían como inquisidores. Una vez recibidos sus testimonios, desde el arzobispado se dirigieron a Roma para informar y

${ }^{31}$ ACDF, St. St. BB 4d.

${ }^{32}$ Sobre la estrecha colaboración de M. Vaaz con el virrey, G. Coniglio, Il viceregno di Napoli nel sec. XVII (Roma, 1955), 199-200. Añade información al respecto ENCISO, Linaje, poder y cultura, 352-409.

${ }^{33}$ SABAtinI, «Alleati? Nemici? I portoghesi», 21-24. 
pedir instrucciones sobre el modo de proceder en el caso. En la carta de respuesta de la Congregación, se recordaba que:

La famiglia Vaez che dimora in Napoli et in altre parti di cotesto Regno è stata in varii tempi data a questa $\mathrm{S}$. Congregatione data per sospetta di giudaismo, si hebbero dal S. Cardinale Caraffa antecessore di V. E. le denuntie e depositioni fatte in cotesto tribunale: dall'anno 1616 delle quali ella ci ha mandato copia, furono anco dati sopra di esse alcuni ordini che non si eseguirono con quell'effetto che si desiderava, del 1626, del 36, et ultimamente del 1646, si sono ricevute nuove denuntie che non si sono già mai intieramente verificate $[\ldots]^{34}$.

A la sesión de la Congregación se habían llevado las testificaciones procedentes de los dos tribunales, el diocesano y el del inquisidor delegado, los cardenales las habían estudiado conjuntamente y se habían pronunciado. En su mandamiento se traslucía una crítica con respecto a la ejecución de las órdenes dadas en el pasado, crítica que se dirigía a ambas instancias. Dicho esto, los cardenales estimaron que, después de las recientes delaciones, se debía proceder al registro de la casa de las Vaaz, además de examinar al resto de los criados, pero antes de que se ejecutase pidieron que el arzobispo propusiese

[...] qual modo si può tenere per non incontrare difficoltà di procedere alla perquisitione nella casa di Anna e di Beatrice, e successivamente di proseguire e terminare cotesta causa si grave [...] Restarà dunque V. E. servita di secondare i sensi di Sua B. nell'uno e nell'altro capo perche dalla prudenza sola e dal zelo personale di V.E. può seguirsi la strada di poter castigare cotesti rei ${ }^{35}$.

A pesar de la orden dada al arzobispo, a pesar de la acumulación de testimonios, a pesar de que se calificase de «tan grave» la causa, ninguno de los Vaaz fue molestado, ni siquiera el núcleo familiar de Anna y Benedetto Vaaz. Y así transcurrió casi una década más, siguiendo esa curiosa cadencia iniciada en 1616 y que no se había interrumpido desde entonces $-1616,1626,1636,1646-$ hasta que se volvieron a pronunciar acusaciones contra los miembros de la familia en torno al fatídico año de la peste.

${ }^{34}$ Carta firmada por el cardenal Barberini, de 29 de agosto de 1648, ASDN, Sant'Ufficio 153.1921.

3529 de agosto de 1648, ASDN, Sant'Ufficio 153.1921. 
La peste de 1656 se llevó por delante a monseñor Tamburello, cuando cumplía trece años de inquisidor delegado en el Reino de Nápoles. Al llegar la noticia a Roma, la Congregación del Santo Oficio, en lugar de nombrar a un nuevo ministro que lo sucediera, decidió posponer dicho nombramiento y encargó al nuncio que asumiese interinamente las competencias en esa materia. Así se le comunicó al arzobispo, el cardenal Filomarino, requiriéndole además su colaboración:

Desidera Nostro Signore col parere di questi miei Eminentissimi, si proseguisca la causa contro cotesti giudaizanti, è per questo effetto à Monsignore Nuntio si manda piena istruttione: Si compiaccia V. E. è con l'autorità, e con la direttione sua assistere a Monsignore Nuntio per il felice proseguimento di causa così importante $[\ldots]^{36}$.

A pesar de su carácter interino, la actuación del nuncio supuso un cambio drástico con respecto al período anterior, porque fue entonces cuando se varió de rumbo frente a los sospechosos de judaizar en secreto. La permisividad mantenida durante décadas por parte de la iglesia en el Reino de Nápoles se interrumpió, dando paso a una etapa de beligerancia represiva en la que los tribunales diocesanos y el inquisidor delegado colaboraron en el ejercicio del Santo Oficio de la Inquisición, siempre bajo la suprema dirección del propio papa, que presidía la Sacra Congregación.

Una vez recibida la comunicación, monseñor Giulio Spinola, que era por entonces el nuncio de la Santa Sede, se hizo cargo del oficio del difunto inquisidor y tuvo acceso a su archivo. Al revisar los papeles más recientes, referidos a los casos de los que se estaba ocupando Tamburello antes de que contrajera la enfermedad, llamó su atención uno que estaba firmado por el virrey. Se trataba de un billete en el cual el conde de Castrillo informaba al inquisidor de que habían llegado a sus manos unas cartas remitidas desde Liorna por un tal David Israel cuyo destinatario o destinatarios estaban encubiertos bajo nombres falsos. No le explicaba cómo habían llegado a sus manos dichas cartas, le mandaba una copia de ellas y le manifestaba sus sospechas de que esas personas fueran judaizantes que estuvieran manteniendo tratos secretos con los judíos livorneses, por lo que el asunto era competencia de la inquisición.

${ }^{36}$ Carta del cardenal Barberini de 25 de agosto de 1657, ASDN, Sant'Ufficio 153.1921. 
El nuncio, considerando la gravedad del asunto, informó a la Congregación, adjuntando una copia de las cartas que habían sido descifradas por el secretario del virrey ${ }^{37}$. A los pocos días, tras recibir la orden de que investigase el caso, solicitó una entrevista con el conde de Castrillo con el fin de obtener más información al respecto. Sin embargo, no sacó nada de sustancia, según comunicó a la Congregación. Debía utilizar otras vías. Viendo que en las listas de la correspondencia que se fijaban en el correo figuraban dos de los nombres que aparecían en las cartas, ordenó al corriere maggiore que vigilase y le informase cuando los hubiese identificado. Así consiguió descubrir que detrás de los nombres falsos se ocultaban Antonio Suárez Coronel y Aniello di Vicariis, a los que llamó inmediatamente a declarar.

Mientras esa investigación se iba desarrollando con el sigilo acostumbrado por el Santo Oficio, reclamó la atención pública la noticia de que el conde de Mola había sido encarcelado por orden del virrey a causa de su modo de proceder como presidente del tribunal que juzgaba un caso de asesinato. El señor don Odoardo Vaaz, juez in criminalibus en la gran corte de Vicaria, presidía el tribunal que estaba juzgando a Flavio Amendola, acusado de asesinar a su rival en los amores de una comediante llamada «La Pomella». Se trataba del hijo del presidente de la Vicaria, Gian Battista Amendola, el cual logró convencer al juez para que demorara el procedimiento de manera que se evitara la aplicación de la forgiudica a su hijo, tal como había mandado el virrey. Éste, cuando lo supo, montó en cólera y ordenó encarcelar al conde en el castillo de Sant'Elmo ${ }^{38}$.

Monseñor Spinola proseguía su investigación sobre las cartas de Liorna cuando recibió la petición de audiencia de una mujer llamada Fiorenza Vaaz, de la que escuchó gravísimas acusaciones contra varios miembros de su familia, incluido su primo el conde de Mola, que se hallaba preso. Simultáneamente, estaba revisando los archivos donde se guardaban las antiguas testificaciones, entre las que leyó la más reciente delación de Cesare Roberti y acudió a interrogarle. Con respecto al conde de Mola, procedió a efectuar el registro de su casa. En su informe destacó que había visto cruces y pinturas de devoción; pero también que había encontrado

\footnotetext{
${ }^{37}$ Carta del nuncio de diciembre de 1656 y la copia de las cartas, ACDF, St. St. BB 4d.

${ }^{38}$ Confuorto, Notizie d'alcune famiglie; I. Fuidoro, Giornali di Napoli dal 1660 al 1680, vol. I, a cura di F. SchltTZER (Napoli, 1934).
} 
una libreta de talones bancarios con los nombres de algunos pobres a los que se daba limosna, lo cual no habría tenido ninguna importancia si no fuera porque -según él mismo señaló- la casa Vaaz tenía la fama de que había instituido un monte para el mantenimiento de algunos pobres secuaces del hebraísmo.

A continuación- como se relataba en el primer sumario redactado en Nápoles el 31 de julio 1659- se decidieron los primeros mandamientos de prisión para el conde de Mola, su hermano Benedetto, su primo Benedetto di Giorgio, Antonio Coronel y Tomaso Ulloa. El conde de Mola y Antonio Coronel, que se hallaban en la cárcel virreinal, fueron entregados por el virrey al nuncio - previa petición formal de este-, para ser recluidos con los demás en la cárcel del Santo Oficio en San Domenico.

El virrey supo desde el principio que el Santo Oficio iba a procesar a los denunciados como judaizantes, porque cuando la Congregación tomó esa decisión, dio instrucciones al nuncio para que, además de requerirle la entrega de los presos

[...] che secretamente e con destrezza impinguasse il processo [...] e col segreto del Sant'Officio comunicasse quest'affare col viceré, e trovandolo inchinato al proseguimento della causa, li intraprendesse con spirito, implorando la sua assistenza, ove fosse stata necessaria $[\ldots]^{39}$.

La respuesta del nuncio, sin embargo, sembraba dudas sobre la reacción del conde de Castrillo y su disposición a cooperar con el Santo Oficio:

In risposta scrive Monseñor Nuntio con lettera del 8 settembre non havere sin' hora fatto mottivo alcuno col Viceré perche non lo trova uniforme nell'operationi, non havendo da che scrisse quel biglietto così zelante al vescovo di Sora, scoperto in esso alcuna inclinatione per cooperare al buon effetto di questo affare, anzi havendole più volte insinuato alla posta esservi lettere dei medessimi correspondenti di Livorno, dalle quali si sperava di cavar lumi, le ha fatte levare senza communicargliele il che forse sarà succeduto per esser morto il segretario che le scifrava. Che inoltre non ha stimato bene per hora communicare col Viceré perche non se le è di qua precisamente scritto,

\footnotetext{
${ }^{39}$ ACDF, St. St. BB3b, f.43r.
} 
se gli inditii, quali presentemente si hanno si stimino sufficienti per venire a cattura, poiché quando non siano tali non pare conveniente, motivando il fatto al Viceré, screditare questi soggetti, et evitarle prurito della confiscatione senza poi poter giuridicamente terminare la causa [...]. Aggiunge che se si giudicasse opportuno hora egli parlarne al Viceré pensarebbe in tal caso trasferirsi da esso all'improviso, e rappresentandole l'importanza del negotio sorprenderlo, e disporlo ad assistenza all'esecutione, il che non sà se le riuscirebbe, quando le parlasse come di negotio da madurarsi; et in tal caso stima fosse utile una lettera particolare della Sacra Congregatione al medessimo Viceré con la quale se le significasse la premura si hà nel negotio è pra presentarle Monseñor Nuntio; e desiderarebbe insieme distinta istruttione, come dovesse procedere ad esecutione, ò sequestri de feudi et altri beni, e con che forma $[\ldots]^{40}$.

La manifiesta desconfianza del nuncio con respecto al virrey parece que desapareció después de la reunión que ambos mantuvieron. Según se comunicó a la Congregación, Castrillo le había manifestado su disposición a colaborar e incluso le había confiado que había ordenado encarcelar al conde de Mola porque

[...] non era bene animato al regio servitio e che pratticava volontieri con le persone male affette al re e che haveva intelligenze in Roma, et in Livorno dubitava con portughesi hebrei $[\ldots]^{41}$.

La misma buena disposición debió encontrar en el sucesor de Castrillo, el conde de Peñaranda, con quien trató desde enero de 1659 sin que al parecer surgiera ningún desencuentro acerca de los asuntos del Santo Oficio.

En el sumario abierto contra el conde de Mola y su mujer Gratia, además de los que estaban presos con él y sus mujeres respectivas, constaban los nombres de más de treinta personas señaladas como judaizantes, de las cuales la mayoría pertenecía a las diferentes ramas del linaje de los Vaaz, pero ya figuraban dos que formaban parte del círculo familiar de los Vargas. Consideraron tan abultado el número de personas sobre las que pesaban indicios de judaísmo, que acordaron dividirlo en dos sumarios.

\footnotetext{
${ }^{40}$ ACDF, St. St. BB3b, ff. 43r-45v.

${ }^{41}$ ACDF, St. St. BB4d.
} 
En los últimos meses de 1659, la Congregación tomó dos decisiones importantes. En octubre ordenó el traslado a Roma de los cinco primeros reos, que llevaban más de un año de prisión en Nápoles. A continuación, decidió poner fin al período de interinidad en el que el nuncio había asumido las funciones de inquisidor delegado, nombrando para este puesto a monseñor Camillo Piazza, obispo de Dragonia, que comenzó a ejercerlo en el mes de diciembre ${ }^{42}$. Con ese nombramiento, el aparato inquisitorial en el reino se veía notablemente reforzado, puesto que el nuevo inquisidor se dedicaría exclusivamente a las causas de fe, para lo cual contaría, además, con la ayuda del nuncio.

En el mes de diciembre, el nuncio presentó formalmente ante el virrey Peñaranda al recién nombrado inquisidor delegado, que se instaló en el monasterio de Santa Maria delle Grazie, en cuyas cárceles también fueron recluidos algunos procesados ${ }^{43}$. El nuevo inquisidor, además de concluir las causas de los Vaaz, inició las de los Vargas, contra los que procedió muy rápidamente, pues apenas unas semanas después de su llegada se efectuaron los primeros arrestos. A comienzos de 1660, fueron apresados en Nápoles, entre otros, Brigida Barone con su marido y sus hijos, también Giovanni Vargas, el único hijo vivo de Alonso Vargas, todos los cuales fueron trasladados a Roma en el mes de febrero y encerrados en las cárceles del Santo Oficio junto a los hermanos Vaaz. Monseñor Piazza desplegaba una trepidante actividad que se ve reflejada en el encadenamiento de prisiones, audiencias y correspondencia mantenida con la Congregación durante el año y medio escaso que ejerció su cargo, hasta primeros de abril de 1661.

Poco antes del nombramiento del inquisidor delegado, la Congregación había tomado otra decisión de gran importancia en el desarrollo de la campaña represiva. Había ordenado que una parte de los presos fueran trasladados a Roma, dejando al resto en Nápoles. Esa decisión los dividía en dos categorías: los que consideraba que debían ser juzgados directamente por la Congregación y los que quedaban bajo la jurisdicción directa de su inquisidor delegado en Nápoles, al que atribuyeron una evidente preeminencia respecto a los tribunales de las diócesis. Estos fueron

\footnotetext{
${ }^{42}$ Amaвile, Il Santo Officio dell'Inquisizione, 31.

${ }^{43}$ A principios de diciembre 1659, el virrey comunicó al Collaterale que el nuncio le había presentado a monseñor Piazza, ver SABATINI, «Alleati? Nemici? I portoghesi», 29-30. 
colocados en un segundo plano al limitar su actuación a la fase inicial del proceso. Ejecutarían las prisiones, darían audiencias, pero no podrían concluir las causas, porque deberían trasladar a los reos a la capital para entregárselos a monseñor Piazza. Sin duda, se trataba de una medida que reforzaba el control de la Congregación sobre el conjunto de los procesos.

La campaña represiva se había ido expandiendo fuera de la capital, siguiendo la dirección que señalaban las acusaciones. Mientras el nuncio llevaba adelante los procesos en Nápoles, en Lecce era el tribunal episcopal el que procedía, recibiendo delaciones, examinando a los testigos y ordenando las prisiones, siempre bajo las directrices de la Congregación, que intervenía de manera sistemática. Admitió, por ejemplo, la súplica del duque de San Donato para no someterse al tribunal del obispo y presentarse en Nápoles ante el inquisidor Piazza para reconocer sus culpas.

En Salerno, donde residía una buena parte de las familias del círculo de los Vargas, fue el vicario del arzobispo el que inició las causas contra las mismas. Examinó a los testigos, mandó ejecutar las prisiones y se ocupó de enviar a los reos a Nápoles, entre los cuales se hallaron la criada Giustina Gratiana y el marqués de la Guardia. El obispo de Bitonto, donde residían algunos de los Barone, colaboró también en esa campaña. Examinó a los testigos, envió las testificaciones a monseñor Piazza y retuvo a los presos hasta que se le requirió que los trasladara a Nápoles.

En la ciudad de Nápoles, donde residían el inquisidor delegado y el arzobispo de la diócesis, también se impuso la colaboración entre ambas instancias, siempre sometida a la preeminencia del inquisidor delegado, como se le hizo saber al arzobispo a través del nuncio en el momento en el que la Congregación decidió proceder contra los judaizantes

[...] che secretamente e con destrezza impinguasse il processo, examinando quelli che si asserivano informati [...] e col Cardinale Arcivescovo confidasse il negotio regolandosi conforme l'istruttione se le mandava $[\ldots]^{44}$.

Queda claro que Su Santidad, al frente de la Congregación, se reservaba y ejercía la suprema autoridad. Y tuvo la última palabra hasta la resolución definitiva de los procesos. En todos los casos, tanto para los

\footnotetext{
${ }^{44}$ ACDF, St. St. BB3b, ff. 43r-45v.
} 
presos que se hallaban en Roma como para los que habían permanecido en Nápoles, fueron los cardenales, y no el inquisidor delegado, los que dictaron las sentencias y determinaron las penas.

En mayo de 1660 llegaron a las cárceles de Roma cuatro personas más del círculo de los Vargas: las dos hermanas Barbuta con los dos hijos de una de ellas. Para entonces, los procesos de los hermanos Vaaz estaban muy avanzados. A mediados de septiembre, la Congregación ordenó que se hiciesen de oficio sus defensas, ya que ellos habían renunciado a presentarlas. El procurador de los reos, Gio Zuffi, elaboró prácticamente un único modelo de defensa para todos, en el que alegaba en su descargo la espontaneidad de la confesión, tanto para los que habían confesado después de hallarse en prisión como para los que se presentaron antes de ser llamados. Seguramente atendiendo a una demanda compartida por los procesados y sus familias, además de tratar de que se les rebajasen las penas, solicitaba que no fueran sometidos a la vergüenza de la abjuración pública.

Una vez conocidas las defensas, la Congregación procedió a votar las causas, las de los reos de Roma y las de los de Nápoles. Considerándolos judaizantes confesos, fueron condenados a abjurar de sus errores; a unos se les impuso la abjuración de vehementi, que indicaba la grave sospecha que recaía sobre ellos, y a otros la más grave abjuración de formali ${ }^{45}$. Ambas llevaban aparejada la solemnidad de la humillación pública; no obstante, los cardenales permitieron excepciones en determinados casos dejando que se pronunciasen a puerta cerrada. Para la mayoría dictaron penas de cárcel de duración variable: perpetua, diez o cinco años.

En los periódicos de Nápoles, se publicó la noticia de que el día de san Silvestre el conde de Mola y su hermano Benedetto habían abjurado de la ley hebraica y habían sido condenados a cárcel perpetua y a pagar dos mil quinientos ducados por los gastos hechos por el tribunal para el servicio de sus personas ${ }^{46}$. Efectivamente, se había celebrado en Roma, en Santa Maria sopra Minerva, el auto de fe en el que salieron los primeros presos, entre los que se contaba el conde de Mola. A la ceremonia, no sólo asistieron los cardenales de la Congregación, sino todo aquel que pudo hacerse un hueco, porque finalmente los cardenales decidieron en contra

${ }^{45}$ E. BRAmbilla, «Abiura», en Dizionario storico dell'Inquisizione, vol. I, 5-6.

${ }^{46} 5$ gennaio 1661, FuIdoro, Giornali di Napoli, 69. 
del voto de la mayoría de los consultores y de las peticiones que se les habían hecho llegar de una ceremonia a puerta cerrada ${ }^{47}$.

Los presos que habían permanecido en Nápoles fueron conociendo las sentencias a través del inquisidor Piazza. Trece de ellos fueron calificados judaizantes confesos como los anteriores y, en consecuencia, padecieron las mismas condenas. Dos meses y pico después del auto de fe celebrado en Roma, abjuraron en Nápoles, en la iglesia de San Domenico Maggiore, Gratia Vaaz di Riviera, su marido y su hijo, pero a finales de mayo aún quedaban procesos por concluir ${ }^{48}$.

La celebración de los solemnes autos de fe -escenificación del triunfo de la misión del Santo Oficio sobre los herejes- no sellaron en aquella ocasión la conclusión de la campaña represiva. Quedaban procesos en curso y otros por abrir. Y en aquellas circunstancias, se desencadenó en la ciudad un intrincado conflicto en el que intervinieron los miembros de la oligarquía urbana y el propio virrey.

Hasta entonces, no se había producido ningún incidente en la relación entre el Santo Oficio y el virrey. El conde de Peñaranda no había puesto ninguna objeción a la hora de entregar a los reos que hallándose en la cárcel de Vicaria fueron reclamados por los inquisidores, ni al traslado de los presos a Roma que solicitó el nuncio al Collaterale. Incluso ayudó a que se ejecutaran las prisiones de los Vargas, como reconoció el inquisidor Piazza al cardenal Chigi ${ }^{49}$. Sin embargo, como se señalaba anticipadamente desde Roma, había un asunto que podría provocar el desacuerdo entre el papa y el virrey, y era este el de la confiscación de los bienes de los reos. Por eso, cuando se produjo la confesión de los presos de Roma, el cardenal Chigi escribió a monseñor Piazza para comunicárselo y para darle la siguiente instrucción

[...] di avvisare il viceré che però avrebbe dovuto dare il giuramento del segreto, raccomandava al Piazza di introdurre con il viceré il discorso della confisca dei beni, ricordando che il fine del papa non era quello di far eseguire tale provvedimento, in quanto

\footnotetext{
${ }^{47}$ Referido en carta de 11 de enero de 1661 del nuncio al Secretario de Estado, SIRAGo, «L'inserimento di una famiglia ebraica», 140 .

${ }^{48}$ FuIdORO, Giornali di Napoli, 74.

4910 enero 1660: escribió Piazza que esas prisiones se habían ejecutado «con l'aiuto del braccio del Sig. viceré», cf. SIRAGO, «L'inserimento di una famiglia ebraica», 139.
} 
ciò sarebbe risultato dannoso per la quiete pubblica, ordinando altre carcerazioni per lo più parenti del conte, indiziati in seguito alla confessione sua e del fratello $[\ldots]^{50}$.

Como se había anunciado, la buena relación que unía a Peñaranda con el papa Alessandro VII no evitó el conflicto cuando el Consiglio Collaterale decretó la confiscación por parte del fisco regio de los bienes del conde de Mola ${ }^{51}$. Monseñor Piazza -siguiendo las instrucciones que se le habían dado desde la Santa Sede- exigió que se le restituyesen. El virrey, por su parte, se hallaba muy preocupado por la sentencia definitiva que debía pronunciar la Congregación en la causa del conde de Mola, y así se lo manifestó a monseñor Piazza. Se veía comprometido y acosado por las presiones que sobre él se ejercían y de las que fue portavoz el inquisidor en la carta que se leyó:

[...] Per la terminatione di causa si considerabile, mi permetterà V.S. che io le rappresenti i sentimenti del signore Vicere, quale in più occasioni ha mostrato non ordinario desiderio di verderne qualche publica dimostratione o almeno intenderne nuova dell'esecutione, acciò non si possa apprendere che il sant'officio dopo tanti apparati habbia fatta una carriera in suo grandissimo discapito, e che egli contro la volontà di tutti questi Ministri Regii, habbia vanamente condisceso alla trasportatione costi del Conte di Mola Giudice perpetuo di Vicaria, e degli altri correi, il che mi replicò in quest'ultima udienza con maggiore premura et efficacia, per essersi sparsa voce in questa città (com'egli mi assicurò, et io ne havevo havuto prima qualche odore) che essendo stata scoperta l'innocenza del sudetto Conte e degli altri carcerati havrebbero quanto prima ottenuta la totale liberatione $[\ldots]^{52}$

Monseñor Piazza cumplió con su misión encargándose de que se celebrase en Nápoles el auto de fe de 27 de marzo de 1661. Pero su triunfo fue verdaderamente efímero, porque a los pocos días los linajes de la oligarquía urbana se levantaron en su contra y exigieron su expulsión inme-

${ }^{50}$ Carta de 27 de marzo de 1660, cf. SIRAGo, «L'inserimento di una famiglia ebraica», 140. Reconstruye además el largo contencioso de devolución de los bienes y retención de la posesión de Mola.

${ }^{51}$ ASN, Collaterale, Notazioni, vol. 65, c. 27r. Referencia en SAbatinI, «Alleati? Nemici? I portoghesi», 31.

${ }^{52}$ ACDF, St. St. BB4d. 
diata. La Santa Sede dispuso que la decisión la tomaran conjuntamente el virrey y el nuncio, que optaron por su marcha ${ }^{53}$. El conflicto que se había desatado no se ceñía, sin embargo, al rechazo a la actuación particular de Piazza, ni estaba únicamente relacionado con el litigio de la confiscación de bienes al conde de Mola. Estalló por un asunto que nada tenía que ver con los procesos de los judaizantes, sino con los miembros del linaje del conde de Conversano, a quienes el inquisidor consideró implicados en un delito de proposiciones sospechosas de herejía ${ }^{54}$. La intervención del virrey lo colocó desde ese momento en el núcleo del conflicto, que fue ampliándose y haciéndose cada vez más complejo. Las demandas de los diputados de los seggi con respecto a la exclusión de la inquisición delegada y en contra de la confiscación de bienes, sus manifestaciones al respecto, así como las posiciones del virrey y del papa durante los meses que duró el conflicto, introducen problemas que rebasan con mucho el de los cristianos nuevos; si bien es cierto que la campaña inquisitorial contra ellos y sus derivaciones se presentan enredadas en dichos problemas ${ }^{55}$.

\section{Epílogo}

No todos los miembros del linaje Vaaz contra los que había indicios de que judaizaban en secreto fueron procesados. Tenemos la certeza de que padecieron un proceso inquisitorial el conde de Mola y sus hermanos Benedetto, Gratia y Fiorenza; sus parientes en Nápoles Benedetto di Giorgio y su mujer, así como Gratia Vaaz di Riviera, su marido y su hijo, Isabella Vaaz di Sousa y Antonio Coronel y su mujer. De los que residían fuera de la ciudad, en las provincias de Bari y Terra d'Otranto, el duque de San Donato, su mujer y su suegra, así como la mujer y los hijos de Francisco Gómez Acosta.

En cuanto a los agrupados en torno a los Vargas, la información es más incompleta. Sabemos que, como los Vaaz, unos fueron procesados en Roma y otros permanecieron en Nápoles, pero hasta el momento no conozco la par-

${ }^{53}$ Amabile, Il Santo Officio dell'Inquisizione, 45.

${ }^{54}$ Fuidoro, Giornali di Napoli, 76-90. G. Galasso, Napoli spagnola dopo Masaniello. Politica, cultura, società (Firenze, 1982) vol. I., 63-64.

${ }_{55}^{5}$ AmaвiLE, Il Santo Officio dell'Inquisizione, 41-52. 
te final de sus procesos. Giovanni Vargas y los cinco miembros de la familia Gaetani estuvieron en las cárceles del Santo Oficio en Roma. También las hermanas Barbuta con los dos hijos de una de ellas. Y en Nápoles, en San Domenico Maggiore, estuvo Aniello di Vicariis, el principal delator, con los presos que habían sido trasladados desde Salerno y varias criadas.

Además de esas personas, los sumarios recogieron los indicios hallados contra muchos más, pero parece que no se procedió contra ellos. Como fue el caso de Gio M. ${ }^{a}$ Capece o de Teresa y Nicolò Greco. Finalmente, se añadieron testificaciones sueltas que acrecentaron la nómina de los denunciados.

No se abrieron procesos contra los muertos, aunque había unos cuantos sobre los que pesaban graves testificaciones, como era el caso del consejero Vargas, acusado por varios testigos de que había judaizado mientras vivió. Lo mismo que repitieron sobre la familia de su mujer, los Nave y los Aiello, cuyos nombres han gozado hasta hoy del prestigio reservado a las casas principales y sin tacha.

Tampoco parece que se concluyeran los procesos de los que murieron durante los mismos, como Francisco Gómez Acosta, que falleció en Lecce de una apoplejía que le impidió declarar, Tomaso Ulloa, que murió en la cárcel de Roma, y Beatrice Vaaz, la mujer de Henrico Coronel, que se tiró por una ventana de su propia casa después de haber confesado el judaísmo.

Pocos días después de la celebración del auto de fe en Nápoles, el inquisidor Piazza se vio obligado a abandonar precipitadamente la ciudad. Tras su partida, como había ocurrido antes de su llegada, las competencias inquisitoriales pasaron al nuncio, que las retendría mientras la Congregación no delegara en un nuevo inquisidor. En los últimos días del año 1662, fray Serafino Candia, archivero del Santo Oficio de Nápoles, daba su parecer a la Congregación sobre el estado en el que se encontraba en esos momentos la acción inquisitorial y sobre cómo se debería proceder en adelante. Escribía desde el palacio de la Minerva en Roma, donde se alojaba, y lo hacía a petición de la propia Congregación. Decía así:

[...] In quanto poi à quello che si potrebbe fare à mio giuditio sarebbe l'aspettare, che pigli piede il nuovo ministro in quel Regno non potendo adesso il Fisco impinguare senza potere carcerare ne chiamare che quel pocho che si fà adesso è mera destrezza, prudenza, 
e zelo di Monsignore Ill.mo Nuntio, e forsi ch'à queste amarezze che prova il Tribunale ci mena anco la mano qualche inditiato, e parente d'inditiato d'hebraismo $[\ldots]^{56}$.

Una vez que fuera relevado el nuncio de las competencias inquisitoriales, el nuevo inquisidor debería proseguir la campaña contra los judaizantes, para lo cual proponía diferentes actuaciones: ejecutar órdenes que ya habían sido reiteradas veces dadas por la Congregación, como la de encarcelar al marqués de la Guardia, no solo por judaizante sino por protector en sus tierras de otros muchos; continuar la causa de la huida de uno de los principales testigos, Aniello de Vicariis, y sus cómplices; además, concluir los procesos ya abiertos y ejecutar las prisiones ya ordenadas. Todo ello exigía la intervención en diferentes lugares del reino, especialmente en Salerno, donde residían el marqués de la Guardia y los parientes de Aniello de Vicariis, y en Bitonto, donde deberían iniciarse nuevos procesos. Fray Serafino advertía de que habría que mandar a Bitonto a un prelado experto en las cosas del Santo Oficio, o al menos a una persona que le asesorase, para lo cual proponía a Paulo Riva mastro d'atti del Santo Oficio de Nápoles, al que tenía por persona incorrupta, muy informada y con gran experiencia, tanto que recomendaba que el nuevo ministro no se desprendiese nunca de él.

En abril de 1663, Alessandro Crescenzi, obispo de Bitonto, fue nombrado inquisidor delegado en Nápoles ${ }^{57}$. Cumplía el requisito de ser obispo del reino, con lo cual se daba cierta satisfacción a las exigencias de la oligarquía municipal. Aunque sin duda su nombramiento certificaba la autoridad de la Inquisición romana, que imponía a su inquisidor delegado a pesar de las protestas que levantaba. El nuevo ministro tomó posesión de su cargo en Nápoles, pero no parece que continuara la campaña represiva que se había iniciado varios años antes contra los judaizantes del reino. La conclusión de esta historia está por hacer, tanto en lo que se refiere al Santo Oficio como a las familias que formaron la comunidad de cristianos nuevos.

Recibido: $15 / 12 / 2012$

Aceptado: 27/12/2012

\footnotetext{
${ }^{56}$ ACDF, St. St. BB4d.

${ }^{57}$ Amabile, Il Santo Officio dell'Inquisizione, 52.
} 